\title{
Book review: Crime and Everyday Life by Marcus Felson and Mary Eckert, 5th edition
}

\author{
Pieter H. Hartel ${ }^{*}$ (D) and Marianne Junger
}

\author{
Book details \\ Marcus Felson \\ Crime and Everyday Life. \\ Texas State University and Mary Eckert-MA Eckert Consulting, LLC, 2016. \\ SAGE Publications, Inc., 240 pages
}

Marcus Felson has recently published the fifth edition of his introduction to the study of crime. In this edition he collaborated with Dr. Mary Eckert. It seems to us, having read and looked at various versions that, in the present version, Felson and Eckert found the right form.

Crime and Everyday Life is an excellent book. It is not a dry academic text but a very readable account of crime in our everyday life. The book debunks common fallacies. The authors explain rational decision-making by offenders-from the offender's perspective (Chapter 3). They include chapters on violence and the role of situations for violent behaviour (Chapter 4). Violence does not require a unique theory, as some psychiatrists and psychologists may believe. The authors describe the role of people, processes and technology in crime (Chapter 5).

The emphasis of the book is on the routine activities of people in everyday life. The processes and technologies that govern our lives largely determine these routine activities. Redesigning the processes and deploying appropriate technologies can increase as well as reduce crime. The authors present simple recipes that can be used to prevent common crime. They show that the systematic use of the principles of the situational approach can help to prevent crime (Chapter 10). Each of the 13 short but informative chapters is concluded by a summary of the main points and a list of projects and challenges for the student of crime.

\footnotetext{
*Correspondence: pieter.hartel@utwente.nl
} University of Twente, Enschede, The Netherlands
The book has many strengths. First, and most important, the crime science approach can be used in practice for crime prevention. The authors make a compelling case that studying the modus operandi and the context of crime helps to develop effective crime prevention. This is backed-up by the many examples developed in the book. It is also supported by several recent studies that showed how the crime drop that has been assessed in many Western countries (Blumstein and Wallman 2005) can be attributed to increases in security. The 'security' hypothesis is an application of the principles of the situational approach as explained in the book (see, for instance Farrell 2013).

Another interesting aspect of the book is that while explaining the situational approach, the authors explain some basics on human nature. For instance, when they explain that people are quite strict when others break the law and attribute this to poor character, but explain away their own misdeeds by pointing at the situation. They also emphasize that the motives for crime are part of the typical motives that drive all human beings (pp. 58-59): all of us desire goods and money, want to take vengeance and 'restore justice' or protect self-image. There is nothing deviant to these motives; it is the use of illegal methods that leads to crime.

There are a few things that we believe might be improved in the next edition. We see two points. Sometimes, the authors perhaps oversimplify their explanations. They state, that offenders are usually more afraid of each other than of the police. Also, they mention that 
active offenders have 'very high rates of victimization plus a tendency toward injury and health problems.' This is an important insight that is explained in three sentences without any references. Indeed, offenders pay a high cost in terms of higher involvement in accidents, illness and higher mortality rates. There is a broad literature to substantiate this as one of us (Junger and Tremblay 1999; van Nieuwenhuijzen et al. 2009) and many others (Laub and Vaillant 2000; Shepherd et al. 2002) showed. Here and there, some additional explanation and additional references could be added.

Another point that we want to mention is the near absence of cyberspace as the new environment for crime. The authors explain how four stages in the history of everyday life illustrate the influence of technology. But everyday life is continually evolving, and the fourth stage is probably already behind us. In various places the authors suggest that the recent technology of the Internet may well change everyday life considerably. We certainly agree. The fifth stage would then be "The Connected World". It is not only the Internet with all its services as we know it today, but the connected world is expanding already into the Internet of Things, where every object is connected too. In the next version of the book this fifth phase deserves a place. Below we describe some of the issues that could be discussed.

The internet has invaded our lives at every single moment of the day. People spend more time online than watching TV. At home children are no longer supervised because their parents have no idea what their children are doing online. We share our most intimate details on social networking sites. We buy and sell online, we do our banking and tax returns online. All this creates opportunity for the motivated offender.

The internet gives offenders access to a global pool of targets. The latter are not too familiar with the new modus operandi, such as phishing and malware. Most targets do not have sufficient protective technology installed, such as an up-to-date operating system and anti-virus. Many of our computers are not even controlled by their owners anymore because they are part of a Botnet. The targets are basically sitting ducks.

In sum, in the connected world, each user is a potential offender as well as a potential target more than ever before.

Despite these difficulties, a number of studies investigated whether the RAT applies to online crime. Several studies reported that specific online behaviours increase the likelihood of cybercrime victimization. Risk taking, such as the tendency to easily click on links, is related to general online victimization (Choi 2008). Also, time spent purchasing goods and time spent on online forums is related to consumer fraud (van Wilsem 2013a), and time spent online and on social media is related to online harassment victimization (Holt and Bossler 2008; van Wilsem 2013b). In each of these studies increased exposure was associated with increased chances of victimization. Overall, a recent review concluded that traditional criminological theories, including RAT, are supported by cyberspace research (Holt and Bossler 2014), reinforcing the idea that cybercrime resembles traditional crime 'old wine in new bottles' (Grabosky 2001).

Besides supportive findings, some studies found that many measures of routine activities were not related to victimization. For instance, Ngo and Paternoster (2011) reported that time spent purchasing goods and time spent emailing were unrelated to seven types of cybercrime victimization. Similarly, Holt and Bossler (2013) reported that having a malware infection on one's pc was unrelated to online shopping, e-mailing and time spent texting/instant messaging.

There are many studies of interventions that prevent ordinary crime. The book gives many examples, and more can be found on http://www.popcenter.org. A similar corpus of work that studies interventions against cybercrime should be high on the research agenda, so that the next edition of the book will be able to represent the most interesting cases too.

Despite these two points for improvement, Felson and Eckert's book combines a strong scientific approach with sound theory while being enjoyable to read. We can therefore encourage all students of crime to read it.

\section{Authors' contributions \\ Both authors contributed read the book and the related literature and each wrote about $50 \%$ of the review. Both authors read and approved the final manuscript.}

\section{Acknowledgements}

We are grateful for SAGE publications to send us a review copy of the book.

Competing interests

The authors declare that they have no competing interests.

Received: 11 January 2016 Accepted: 4 August 2016

Published online: 09 August 2016

\footnotetext{
References

Blumstein, A., \& Wallman, J. (2005). The crime drop in America. Cambridge: Cambridge University Press.

Choi, K.-S. (2008). Computer crime victimization and integrated theory: an empirical assessment. Int J Cyber Criminol, 2(1), 308-333.

Farrell, G. (2013). Five tests for a theory of the crime drop. Crime Sci, 2, 1-8.

Grabosky, P. N. (2001). Virtual criminality: old wine in new bottles? Soc Leg Stud, 10, 243-249.

Holt, T. J., \& Bossler, A. M. (2008). Examining the applicability of lifestyle-routine activities theory for cybercrime victimization. Deviant Behav, 30, 1-25.

Holt, T. J., \& Bossler, A. M. (2013). Examining the relationship between routine activities and malware infection indicators. J Contemp Crim Justice, 29, $420-436$.
} 
Holt, T. J., \& Bossler, A. M. (2014). An assessment of the current state of cybercrime scholarship. Deviant Behav, 35, 20-40.

Junger, M., \& Tremblay, R. E. (1999). Self-control, accidents and crime. Crim Justice Behav, 26, 485-501.

Laub, J. H., \& Vaillant, G. E. (2000). Delinquency and mortality: a 50-year followup study of 1,000 delinquent and nondelinquent boys. Am J Psychiatry, 157, 96-102.

Ngo, F. T., \& Paternoster, R. (2011). Cybercrime victimization: an examination of individual and situational level factors. Int J Cyber Criminol, 5(1), 773-793.

Shepherd, J. P., Farrington, D., \& Potts, J. (2002). Relations between offending, injury and illness. J R Soc Med, 95, 539-544. van Nieuwenhuijzen, M., Junger, M., Velderman, M. K., et al. (2009). Clustering of health-compromising behavior and delinquency in adolescents and adults in the Dutch population. Prev Med, 48, 572-578.

van Wilsem, J. (2013a). 'Bought it, but never got it'. Assessing risk factors for online consumer fraud victimization. Eur Sociol Rev, 29, 168-178.

van Wilsem, J. (2013b). Hacking and harassment—do they have something in common? Comparing risk factors for online victimization. J Contemp Crim Justice, 29(4), 437-453.

\section{Submit your manuscript to a SpringerOpen ${ }^{\circ}$ journal and benefit from:}

- Convenient online submission

\section{- Rigorous peer review}

Immediate publication on acceptance

- Open access: articles freely available online

- High visibility within the field

- Retaining the copyright to your article 